\title{
Revisiting Primary English Teachers' Critical Reflections on Coursebook Usage
}

\author{
Senem Sahin \\ University of Augsburg, German \\ senemsahin@philhist.uni-augsburg.de
}

\begin{abstract}
This study of 30 primary teachers of English in Germany used questionnaires to explore their critical reflections on coursebook usage in classrooms. The research questions were: What are primary school teachers' perceptions of English language teaching materials? What materials are used by primary school English language teachers? What are their reasons for using certain materials? What characteristics define good language teaching materials for primary school English teachers? The participants mostly prefer implementing their own self-designed materials in combination with coursebooks. Given that preparing personal primary school teaching materials is quite timeconsuming, the teachers' arguments for their choice should be explored further to optimize English language teaching. Some argued that self-designed materials are more adjustable to the needs of their students and more authentic. The paper proposes some strategies for striking a balance between teaching English with and without a coursebook, such as making coursebook learning activities more interactive and raising awareness of effective coursebook selection. Different stakeholders can thus collect useful ideas for improvement, including teacher trainers, teachers, student teachers, school administrators, and publishers.
\end{abstract}

\section{Keywords}

teaching English; course book selection; primary school

\section{Introduction}

"Open up your book on page three, please!" This sentence was one of the favorite opening instructions of my own English teachers when I was a pupil. We all had English coursebooks designed by international publishers from one of the BANA countries, namely Britain, Australia, and North America (Canagarajah, 1999). On the one hand, we really enjoyed the beautifully colored chapters and creative activities like project work; on the other hand, we sometimes experienced difficulties relating to unfamiliar cultural elements like celebrating Easter. Changing from a student's perspective to the teacher's after becoming a teacher of English, my feelings surprisingly did not change because, besides having fun in working with creative activities I had to design extra materials to explain certain cultural issues. My long background of using coursebooks in different contexts has now become one of my research interests as a teacher trainer and life-long learner. Such prior learning and teaching experiences, according to many scholars (e.g. Lortie, 1975; Almarza, 1996; Bailey et.al, 1996; Golombek, 1998; Numrich, 1996; Peacock, 2004; Freeman, 2002; Noriah, 2011), have a powerful impact on teachers' professional beliefs about language teaching. Richards (1996, p. 283) explains that their beliefs relate to their personal judgement of what constitutes good teaching and how good teaching can be achieved, and to a great extent with the way teachers themselves were taught English. 
In Germany, where each of the sixteen federal state has a different educational philosophy and diverse legal and political circumstances, the experiences and practices of English teachers vary accordingly. In Bavaria, for instance, where the present study was conducted, English only became a mandatory primary school subject in the 2004-2005 school year. Because a specific teacher-training program for becoming a teacher of English for primary schools was only integrated into the university curriculum after that year, the majority of current primary school English teachers have not been trained to teach this subject. Some further factors that must be considered while exploring the critical reflections of these teachers on their coursebook usage are as follows:

1. The tertiary educational background of teachers teaching English is still very heterogeneous.

2. English coursebooks, which are usually designed by German publishers, must comply with each state's content standards.

3. There are only a few regional primary English coursebooks in each state.

4. There is a considerable research gap in this field.

Consequently, teachers currently use many different ELT materials in primary schools. These are mostly self-designed worksheets for different purposes, e.g. supplementing coursebooks (Fuchs et al., 2010, p. 43). Some German scholars have noted the lack of empirical studies regarding this issue while their own teaching observations and small-scale studies have revealed that primary school teachers often devise such teaching materials to replace or supplement the English coursebooks (Heckt, 2005; Bauer, 2010). Given that primary school teachers have little preparation time due to their tight teaching schedules, why do they prefer leaving their "comfort zone" and develop their own materials? Some further research questions to be answered are as follows:

1. What are primary school teachers' perceptions of English language teaching materials?

2. What materials are used by primary school English language teachers?

3. What are their reasons for using certain materials?

4. What aspects define good language teaching materials for primary school English teachers?

After presenting and discussing the results, the paper proposes some ideas for striking a balance between teaching English with and without a coursebook, such as activities for making a coursebook more interactive and raising awareness of effective coursebook selection. Different stakeholders can thus collect useful ideas for improvement, including teacher trainers, teachers, student teachers, school administrators, and publishers.

\section{Review of Literature}

Coursebooks are usually part of a course package with various supplementary materials, such as CDs, a student's book, activity book, and DVDs. Self-designed materials are teaching aids that have been completely or partly developed by teachers for their own teaching context. They either create these materials from scratch or collect, compile, and adapt online and offline resources, e.g. from the Internet, colleagues, or other coursebooks.

Regarding the literature on materials analysis and development, there are many publications discussing the advantages of using coursebooks versus self-designed teaching 
materials (e.g. Hutchinson \& Torres, 1994; Sheldon, 1988; McGrath, 2002; Tomlinson, 2003; Mukundan, 2007). On critical reflection, however, an alternative approach is needed, namely discussing provocative arguments against using either coursebooks or self-designed materials.

\subsection{Arguments against Using Coursebooks}

\section{a. Con 1: Coursebooks are not flexible}

State schools in Germany have a federal curriculum that must be reflected in coursebook selection. Therefore, teachers usually follow coursebooks rigidly to complete them by the end of the school year to fulfill the curricular requirements of the local ministry. Teachers feel overwhelmed with the number of topics to be covered in the lesson plans scripted by coursebooks, which prevents them from diverging from standardized curriculum. Furthermore, because they have to track the structure and outline prescribed in coursebooks, teachers have little opportunity to implement contextual grammar and vocabulary teaching, namely teaching and revising in a meaningful context according to the teaching situation and the topical focus of the lesson.

\section{b. Con 2: Coursebooks do not consider individual differences}

Coursebooks do not usually consider individual differences in given teaching contexts. For example, students entering secondary school in Germany are very heterogeneous in English level, which makes in-class differentiation almost essential for authentic, personalized, and convincing teaching (Criblez \& Nägeli; Stebler, 2010, p. 27). Teachers in Germany expect, for instance, that people with disabilities, disorders, learning difficulties, and different skin colors should be considered in coursebook design to enable integrative and inclusive teaching, e.g. providing extra helpful activities, or including such people in illustrations and pictures of coursebooks.

\section{c. Con 3: Coursebooks are boring}

Coursebooks are sometimes considered boring because they are repeated every year and usually out of date, particularly topics, illustrations, and language due to a rapidly changing world. Teachers therefore have to use their creativity and motivation to update coursebook contents with current topics by also conferring with their students about their interests.

\section{d. Con 4: Coursebooks not contextualized}

Although publishers cooperate with teachers and authors to design local coursebooks, a great number of globally published English teaching materials are not suitable for all teaching contexts. Global coursebooks usually include elements that can be culturally, socially, or ethically unfamiliar to local students. They may find it difficult to understand or relate to certain materials, such as eating pork for Muslim students. Awareness raising concerning materials analysis and selection should therefore become an important part of teacher training programs to enable teachers to handle such sensitive issues in a culturally appropriate manner.

\section{e. Con 5: Coursebooks removes the ownership of teaching from teachers}

Swan (1992) emphasizes that coursebooks can be problematic in freeing teachers from their teaching responsibility: "it is easy to just sit back and operate the system, secure in the belief that the wise and virtuous people who produced the textbook knew what was good for 
us" (1992, p. 2). Teachers and students should be owners of their own teaching and learning process.

\subsection{Arguments against Using Self-designed Materials}

\section{a. Con 1: Self-designed materials prevent standardization}

Self-designed materials are far from enabling standardization across classes within the same school or country. In some settings, where teaching objectives are determined by curricula or exams that students must pass for their further educational career, e.g. Germany's school leaving exam (Abitur) or university entrance exams, it is necessary to have the standardization provided by coursebooks. In support of this view, O'Neill (1982, pp. 106107) argues that many coursebooks are suitable for almost all needs because "there is often a common core of needs shared by a variety of groups in different places studying under different conditions at different times".

\section{b. Con 2: Self-designed materials cannot provide a structure or lesson plan for teaching}

Coursebooks provide teachers with complete guidance and a basic framework. This gives teachers security and helps them save time in lesson planning. Self-designed materials cannot offer this clear structure with clearly marked and signposted phases, regularly scheduled events, and clear and fair turn allocation for student participation (Hutchinson \& Torres, 1994, p. 319).

\section{c. Con 3: Self-designed materials are not suitable for heterogeneous learner profiles}

Self-designed materials can be implemented more suitably with homogenous groups of leaners. However, the majority of learners have different English proficiency levels. Without a resource or guide provided by a coursebook, the teacher must continuously answer the questions of students, which can become complicated and laborious in large classes.

\section{d. Con 4: Self-study materials cannot support individual learning for revision and preparation}

Coursebooks allow students to revise what has been covered, look ahead to forthcoming lessons, and prepare themselves. In this sense, they encourage individual learning outside the classroom by operating as a reference or resource by including, for example, lists, figures, and charts of grammatical rules (Michler, 2005, p. 45). In addition to the reinforcement of autonomous learning, teachers use coursebooks to assign homework and supplementary activities (Sandfuchs, 2010, p. 19). Finally, coursebooks are also used by parents or other people helping students learning languages as a road map.

\section{e. Con 5: Self-designed materials are not practical}

Teachers need a lot of time to design own materials because they have to research, gather, and edit their own materials. Teachers must then invest time in preparing the materials for classroom use, which may cause high material and copying costs. Since homemade materials tend to get damaged or lost very quickly, teachers must also invest more time to protect them, e.g. in storage, sharing, or transporting. 


\section{f. Con 6: Self-designed materials are of poor quality}

Teachers who frequently use online resources and teaching materials borrowed from their colleagues must be attentive because such materials may be of poor quality in language and content. Most self-designed resources may be ineffective because they are badly structured, cause information overload, contain mistakes or inappropriate content. Therefore, teachers, especially novices, must be well equipped with media competency, and materials analysis and development skills to analyze these resources comprehensively and professionally.

\section{g. Con 7: Self-designed materials cannot be used in schools without administrative approval}

Teachers must persuade their colleagues, school administration, and parents to accept self-designed materials. Schools are formal institutions in which education takes place within a specific framework established by educational policy. This in turn determines the curriculum, lesson plans, school-intern regulations, etc. Furthermore, parents wishing to support their children's learning prefer having coursebooks for guidance and reference. This makes it harder for teachers to provide plausible arguments in favor of using self-designed materials for teaching English while abandoning coursebooks.

\section{Methods}

Given the tight schedule of most primary school teachers, this study used a questionnaire in both online and print versions to reach as many participants as possible. The questions were asked in German to make answering easier and thereby increase the response rate.

The questionnaire had 11 questions with various response options, ranging from openended questions to Likert-type scale responses. The first part contained five questions about the participants' socio-demographic and professional background. The following three questions asked participants to state and justify their preferences regarding teaching materials. They were also requested to describe the characteristics of a good primary school English coursebook. They then rated 14 statements about coursebook characteristics using a Likert-type scale. Finally, they could respond to an open-ended question regarding their expectations of future coursebooks for teaching English in primary schools.

Out of 30 participants, 26 were female and 4 were male. Almost half $(\mathrm{N}=14)$ had been working for less than 10 years, of whom 5 had been working for less than 5 years. Nine teachers had between 11 and 20 years of experience while 7 had more than 21 years. The two most experienced teachers have been working for 30 and 36 years. Therefore, half of the participants only began to work in primary schools after English became a mandatory school subject in 2003-04 (15 participants with 13 years of experience or less) whereas the other half had experienced the implementation itself. As well as classes in other subjects, 22 participants taught English in both class 3 and 4. Two thirds $(\mathrm{N}=20)$ had not studied English at university, only 9 studied English as their major subject while for one it was a minor subject.

Finding enough participants was a challenging part of this study despite taking important steps, such as designing the research instrument in the mother tongue, asking clear questions using a variety of response types, cooperating with schools and teacher associations, relying on voluntary participation rather than ministerial assignment, and 
promoting the research at national conferences. This may have been due to the teachers' long working hours and the few English teachers currently working in primary schools.

It was particularly difficult to find enough male participants to have a balanced sample concerning gender. However, it was not a goal of the study to find a representative sample of teachers. Indeed, the percentage of male participants $(13 \%)$ was close to the overall percentage of male primary school teachers in Bavaria, which according to the Bavarian Ministry of Education, was 8\% in 2015-16 (KM Bayern 2016, Schule und Bildung in Bayern, 2016, p. 38). This reflects a global tendency for primary school teaching to be regarded as a female profession.

\section{Discussion}

\subsection{Results}

Only the three teachers who studied English at university stated that they only used the coursebook for their classes. Four teachers had abandoned the coursebook, of whom three had received teacher training to become primary school English teachers. The remaining 23 participants used both coursebooks and other materials. Of these, eight preferred the coursebook over other materials whereas nine preferred other teaching materials.

The most frequent justification for using a coursebook was the abundance of helpful supplementary materials by the publishing houses, such as CDs, DVDs, stories, and teacher's manuals. Second, when a coursebook has a main character, this helps the children identify with the new content and the overall subject. Third, the participants particularly liked the overview and structure that a coursebook provides in that the topics are structured meaningfully and lesson planning hints are included. Fourth, the listening activities and accompanying CDs with native speakers were beneficial as students got a chance to hear authentic usage of the target language and listen to different native speakers. Fifth, the teachers stated that the illustrations are good, along with the ideas and production quality. Regarding illustrations, the teachers mentioned both drawings and photographs within the book and flashcards and pictures in the supplementary materials. The games and activities exemplified the quality of the coursebook as the teachers found them suitable for the age group of their students. Sixth, using a coursebook saved time because teachers do not have to look for materials and pictures himself since no materials need to be copied for the students. Finally, a few participants mentioned that the coursebook was already in stock at the school and that other teachers had been using them the years before.

Regarding justifications for using other materials, teachers reported integrating other materials into their lessons whenever the coursebook failed to offer authentic teaching. For example, they integrated picture storybooks, YouTube clips, and realia into their teaching. Second, some teachers preferred supplementary materials that were more adjustable for diverse learning situations and individual learner differences. Third, other materials allowed them to elaborate on certain topics when the coursebook failed to cover comprehensively, such as through stories, pictures, songs, games, or rhymes. Finally, a few participants included materials about current events, such as the Royals, or special holidays to boost intercultural learning.

Participants offered various examples of other materials in addition to or instead of coursebooks. Many teachers reported creating their own materials at home for their English lessons, such as flashcards, picture cards, worksheets, or games. Second, they mentioned making authentic picture storybooks in various formats, such as mini books for circulating among students in the classroom or large-size books to read in front of the whole class. Third, 
participants mentioned online materials, particularly platforms offering teaching materials specially designed for children, such as the British Council, publishers' websites, and teachers' blogs. Fourth, some teachers used other coursebooks and their supplementary materials, for example from their school library. Fifth, teachers created their own wordpicture cards and collected realia for classroom teaching, such as postcards, souvenirs, menus. They also had diverse collections of games, puzzles, and music CDs. Finally, some participants mentioned cooperating with school colleagues and working groups from other states to exchange materials.

Between them, the participants identified the following six qualities of a good coursebook for learning English in primary school:

1. well-structured and providing a good overview of contents

2. child-friendly with an appealing layout

3. accompanied by useful supplementary materials, such as a teacher's manual, student's book, multimedia materials, and flash cards

4. containing communicative, and differentiated activities

5. complying with the current curriculum

6. being manageable over school year

In question 10, teachers were asked to agree or disagree with 14 statements on a fivelevel Likert scale. Nearly two-thirds $(\mathrm{N}=19)$ of participants totally agreed that course books should offer a variety of supplementary materials. Eighteen teachers agreed in the importance of coursebook layout while four totally agreed. Responses varied regarding the use of a central character or protagonist in every chapter, with 13 teachers disagreeing, seven being neutral, and 12 agreeing. Similarly, 13 teachers disapproved of having a coherent storyline, nine teachers were neutral, and only eight participants agreed.

Responses also varied widely regarding the use of current events in coursebooks. While 10 teachers agreed, 11 were neutral, and nine disagreed. Over two-thirds of participants $(\mathrm{N}=21)$ agreed and six others totally agreed with promoting intercultural competencies with a focus on Great Britain and the USA. Of the remaining three teachers, two were neutral and one disagreed. Next, the participants were asked about their opinion on exercises and activities and whether those should appeal to different learner types. Here, 13 teachers agreed and 17 agreed totally. Almost half $(\mathrm{N}=14)$ agreed that there should be child-friendly drawings rather than authentic photographs while nine were neutral, and seven disagreed.

Nearly half the participants $(\mathrm{N}=13)$ disagreed that differentiation should be managed by the teacher rather than included in the coursebook. This confirms the teachers' earlier opinions about differentiation exercises within course books. However, 8 teachers agreed and 9 were neutral. This might also indicate that differentiation should not be included excessively in coursebooks as some teachers still want to differentiate individually.

A large majority $(\mathrm{N}=21)$ of the teachers agreed that coursebook texts and illustrations should include heterogeneity while eight teachers were neutral and one teacher disagreed totally.

Most teachers either agreed $(\mathrm{N}=12)$ or totally agreed $(\mathrm{N}=12)$ with writing coursebooks solely in the target language whereas one teacher was neutral and five participants disagreed.

Presumably in reflection of research showing that moving around is critical for young learners since they cannot sit still for a whole school day, 25 participants agreed that there should be coursebook tasks that get students moving and acting.

Confirming responses to earlier questions, almost all teachers $(\mathrm{N}=26)$ totally agreed that supplementary materials should include audio CDs with activities to train listening comprehension. Finally, all participants either totally agreed $(\mathrm{N}=25)$ or agreed $(\mathrm{N}=5)$ that coursebooks should offer many communicative opportunities. 
Regarding their expectations or recommendations for future course books, participants suggested that authentic materials, especially storybooks, should not be abridged or simplified for German pupils. Additionally, teachers wanted special days, such as Christmas, to be integrated logically into coursebook chapters and storylines as in real life, in line with the time of year rather than dealt with at the end. Publishers should also provide a regularly updated website for each coursebook with special topics, communicative activities, etc. Finally, one participant noted the lack of any coursebooks for bilingual classes (CLIL lessons).

One of the most important findings of this study is that, despite all the available supplementary online and offline materials, a majority of teachers still use their coursebooks. However, they do not do this blindly; rather, they adapt the books to their students' needs. As many experts argue (Legutke et al., 2009, p. 113; Krenicky, 2004, p. 68), the most effective approach to lesson planning, whether with coursebooks or other materials, is to adjust it for their specific teaching context. Online sources have been used more frequently; however, they are not used in lessons actively or live, but used for lesson preparation by teachers at home. Although the participants expressed satisfaction with their current local coursebooks overall, they wish that there were more authentic supplementary materials and online support for teachers. Finally, they acknowledge that there is no perfect coursebook.

\subsection{Discussion}

Prior to conducting this study, it was predicted that teachers without training for English teaching would prefer using coursebooks more frequently than participants who had studied English to become a primary school English teacher. The assumption was that they lacked the professional background, especially methodology, for teaching languages; hence, they would depend more on teaching with coursebooks. Conversely, it was predicted that younger English teachers would prefer to ignore their coursebooks and teach only with their self-designed materials. However, both these hypotheses were refuted. Regardless of their university background and length of professional experience, participants used both coursebooks and other materials. The latter are usually self-designed and mostly adapted from other coursebooks and their supplementary materials or authentic materials. Unexpectedly, these teachers did not primarily prefer to use the Internet or exchange materials with colleagues.

The participants also showed that they do not support the idea of having a protagonist or main character in coursebooks, e.g. an animal or cartoon figure, who is involved in storylines and other parts of a coursebook. Instead, they favor a coursebook without a storyline that should be followed chapter by chapter. This reflects teachers' tendency to avoid following a coursebook strictly, but rather to complement and supplement it with selfdesigned and self-selected materials. Similarly, their preference for not having a storyline with a main character may indicate that they need flexibility in using a coursebook. This makes sense because primary classrooms reflect German society's heterogeneity, which does not allow teachers to follow a single classroom methodology. Instead, they generally prefer analyzing their own teaching situation before using coursebooks and supplementary materials as departure points for their own individualized teaching.

At first sight, supporting the promotion of intercultural competencies through a focus only on Great Britain and the USA might appear to promote one-sided intercultural teaching because English is a global lingua franca and therefore not only spoken in these countries. However, the teachers stated that including extremely diversified English-speaking cultures can be confusing and overload primary school pupils. Nevertheless, teachers agreed with 
raising awareness of English as a lingua franca by mentioning it in lessons, as implemented in the latest coursebook editions, e.g. explanations with maps or short stories.

The participants recommend that coursebooks should include child-friendly and modern illustrations. However, teachers will still need to supplement und update such features given that the world changes very quickly whereas the coursebooks are only updated every eight years in Bavaria. Indeed, teachers do not always welcome new editions as they have already studied the current coursebook and improved it with their own supplementary materials (Harmer, 2007, p. 181f.; Podromou, 2002, p. 26f.; Ur, 2012, p. 198). A new edition therefore entails significant extra preparation time.

Regarding the inclusion of mother tongue, teachers find curriculum-related explanations in German very useful along with some grammar explanations. However, they prefer that publishers strike a balance by avoiding a big amount of German language.

Some scholars assume to observe fairly often that primary school teachers use more supplementary materials than other teachers (Heckt, 2005; Peschel, 2005; Herbst, 2005; Bauer, 2010). They argue that such materials can be used more flexibly than the coursebooks. Especially less experienced teachers or those without specific training for teaching English as a foreign language state that they need a book to feel secure (Harwood, 2010, p. 20). However, this is problematic because sticking to a standard coursebook without adapting it to the dynamics of a given classroom setting may not be the most motivating way of teaching since the most heterogeneous students in Germany are at primary school.

In this regard, publishing houses should offer free extra materials and more professional development opportunities like seminars and workshops for practitioners to become more familiar with new coursebooks. Teachers should use professional development resources like webinars, blogs, and online chat support. Both sides should cooperate with each other. Finally, while evaluating coursebooks, teachers should be encouraged to use different techniques, e.g. checklist grids (Sahin, 2020, p. 108), to identify their strengths and weaknesses to adapt or supplement them.

\section{Conclusion}

Should teachers now abandon their coursebooks? Even Thornbury (2009), the founder of the Dogme Approach, admits that coursebooks may have advantages, such as including motivating topics and texts for learners. He therefore suggests selecting resources carefully to make lessons more learner centered, e.g. using real life interaction and conversation (Thornbury, 2005, p. 2). However, because English is a lingua franca and learned by millions of people worldwide, it is not commercially feasible for international publishers to produce teaching materials catering for specific local demands in each country. Coursebooks are therefore generally written for a certain market while merely considering the social, cultural, and educational background of the teaching setting (Stranks, 2012, p. 125). Even coursebooks marketed by local publishers are somehow standard and unable to meet the specific expectations of extremely heterogeneous learning groups within one teaching context.

Despite these issues, coursebooks are required in most schools and prescribed for almost every school subject. Teachers should therefore move well beyond simply transferring knowledge from coursebooks to learners; they should become materials analysts and developers to find a healthy balance between using coursebooks, self-designed materials, and supplementary materials in a flexible manner for teaching English. In support of this approach, Halliwell (1992) argues that "there are several things that the teacher can often do 
better than a book" (p. 114). These include conversational speaking and listening practice, adjusting activities in response to the children's reactions, communicating without using words or pictures to support learning of language elements, and implementing learning activities that encourage learners to talk and benefit from interaction (Halliwell, 1992, p. 114). Therefore, teachers should use a coursebook "as a menu from which you choose, rather than a recipe which you follow rigidly" (Brewster, Ellis, \& Girard, 2002, p. 231). In this sense, teachers believe that coursebooks cannot dictate how they should be used. Instead, teachers should decide what topics are suitable or essential for each group of students considering their interests and needs. Teachers then consult with their students to involve them in their decision-making concerning course objectives, activities, etc. Such a democratic method also helps teachers to humanize their teaching (Jordan \& Gray, 2019, p. 444). Soares describes it as follows:

Fortunately, there are professionals that are able to teach with the textbook instead of teaching through it. Therefore, teachers can generate new content from within and from outside the materials by skipping sections, tasks and activities or, conversely, by modifying and adapting these elements to the real purpose of the group and concentrate on interpersonal relationships in the class as well.

Such teachers take a critical attitude towards coursebook contents, based on critical pedagogy (Canagarajah, 1999, pp. 14-15). Aware of hidden curricula in coursebooks, they do not stick to the contents, but search for a more holistic methodology for teaching English. As mentioned earlier, teaching English without a coursebook may not be that suitable for crowded classrooms while teaching English only with a coursebook may not be that affordable for classroom in which teachers have students from lower socio-economic backgrounds. In either case, the teacher matters. Teachers should be methodologically well equipped to choose the best option for the target group of learners. They must know how to choose a coursebook and how to enrich it with supplementary materials according to the given context. Therefore, teacher-training institutions should prepare future teachers by offering seminars about teaching materials analysis, and development. Unfortunately, however, student teachers often only receive their coursebook too late, just before they start their school practicum.

Another issue discussed by some scholars is the assumption that using coursebooks hinders individual learning. However, students, especially slow learners, need a structure. This provides a road map while they are planning their individual learning. Therefore, coursebooks are an ideal departure point and reference for their self-learning outside the classroom based on their personal progression. This makes it crucial to teach students to work autonomously with their coursebooks and other supplementary materials. For instance, from primary school onwards, they need to learn to understand the symbols, abbreviations etc. in coursebooks that indicate certain types of working.

In training novice teachers about materials analysis and development to optimize their teaching by making such decisions, they must be made aware that "teachers do have a word to say concerning the choice of materials to use in the classroom, including the processes of selection, adaptation, writing and replacing materials" (Azaza, 2012, p. 179). There are different ways to change a coursebook to make it more enjoyable and rewarding for both the teacher and the students. These include authentic stories, videos, interactive students' notebooks, and games that captivate the students and keep them motivated and interested in learning.

Teachers must also raise students' awareness of how to use coursebooks in and outside the classroom. Teachers can also learn the SARS techniques (selecting, adapting, rejecting, or supplementing a coursebook). They may be asked, especially for higher grades, how to 
personalize coursebooks and other teaching materials to make them more relevant and meaningful for students. There is a research gap concerning the role of coursebooks in learning from the students' perspective. However, students' critical reflections on the shortcomings of teaching materials is important because students ultimately the target group of coursebook for classroom and individual learning.

Overall, a coursebook is a valuable teaching tool if selected and used appropriately, rather than followed slavishly. Teaching with or without coursebooks should not matter that much if the teacher is teaching enthusiastically. However, if the teacher is not motivated in pursuing a teaching career, even learning with the most interesting book becomes a boring experience for students.

\section{References}

Allwright, R. L. (1990). What Do We Want Teaching Materials For? In R.Rossner and R. Balitho (Eds.), Currents of Change in English Language Teaching (pp. 131-147). Oxford: Oxford University Press.

Almarza, G.G. (1996). Student foreign language teacher's knowledge growth. In D. Freeman \& J.C. Richards (Eds.), Teacher learning in language teaching (pp. 50-78). Cambridge: Cambridge University Press.

Azaza, M. B. M. (2012). Developing and evaluating learner training materials. In H. Emery and F. Gardiner-Hyland (Eds.), Contextualising EFP for Young Learners: International Perspectives on Policy, Practice and Procedure (pp. 179-193). Dubai: TESOL Arabia.

Bailey, K.M. et al. (1996). The language teacher's autobiography: Examining the "apprenticeship of observation." In D. Freeman \&J.c. Richards (Eds.), Teacher Learning in Language Teaching (pp. 11-29). Cambridge: Cambridge University Press.

Bauer, K. (2014). Textbooks and Teaching and Learning Materials. A Case Study from the Early Childhood Classroom, IARTEMe-Journal 3 (2), 81-96. Retrieved from http:// biriwa.com/iartem/ejournal/volume3.2/papers/Bauer_paper_IARTEMEJournal \%20_Vol3No2.pdf [Accessed 01.03.2020].

Brewster, J., Ellis, G. \& Girard, D. (2002). The Primary English Teacher's Guide. Harlow: Pearson Education.

Canagarajah, A. S. (1999). Resisting Linguistic Imperialism in English Teaching. Oxford: Oxford University Press.

Sahin, S. (2020). Developing a Checklist for English Language Teaching Coursebook Analysis, International Journal of Education and Research, 8(1), 107-120.

Criblez, L., Nägeli, A. \& Stebler, R. (2010). Schlussbericht. Begleitung der Einführung des Englischlehrmittels Voices auf der Sekundarstufe I. Zürich: Universität Zürich.

Freeman, D. (2002). The hidden side of the work: Teacher knowledge and learning to teach, Language Teaching, 35, 1-13.

Fuchs, E., Kahlert, J. \& Sandfuchs, U. (eds.) (2010). Schulbuch konkret. Kontexte Produktion - Unterricht. Bad Heilbrunn: Klinkhardt.

Golombek, P.R. (1998). A study of language teachers' personal practical knowledge. TESOL Quarterly, 32, 447-464.

Halliwell, S. (1992). Teaching English in the Primary Classroom. New York: Longman.

Harmer, J. (2007). The Practice of English Language Teaching. Harlow: Longman.

Harwood, N. (2005) (Ed.). English Language Teaching Materials. Stuttgart: Klett.

Heckt, D. H. (2005). Arbeitsblätter von allen Seiten. Grundschule, 37 (12), 6-8.

Herbst, M. (2005). Ein Hoch auf das Arbeitsblatt. Grundschule 37 (12), 15. 
Hutchinson, T. \& Torres, E. (1994). The textbook as agent of change. ELT Journal, 48(4), 315-327.

Jordan, G. \& Gray, H. (2019). We need to talk about coursebooks. ELT Journal, 73(4), 438446.

Jordan, G. (2016). The lose-lose folly of coursebook consumption. [Blog] CriticElt. Retrieved from: https://criticalelt.wordpress.com/2016/12/05/the-lose-lose-folly-of coursebook-consumption/ [Accessed 04.03.2020].

KM Bayern - Bayerisches Staatsministerium für Bildung und Kultus, Wissenschaft und Kunst (2016). Kriterien zur Begutachtung von Lernmitteln. Retrieved from: https://www.km.bayern.de/lehrer/unterricht-und-schulleben/lernmittel.html [Accessed 04.03.2020].

Krenicky, K. (2004). Evaluation eines Lehrwerks für den Fremdsprachenunterricht Englisch in der Grundschule. München: Grin Verlag.

Legutke, M. K., Müller-Hartmann, A. \& Schocker-von-Ditfurth, M. (2009). Teaching English in the Primary School. Stuttgart: Klett Lerntraining.

Lortie, D. (1975). Schoolteacher: A sociological study. Chicago: University of Chicago Press.

Lutzker, P. (2016). Fremdsprachen ohne Lehrbuch. In J. Kiersch; E. Dahl and P. Lutzke (eds.), Fremdsprachen in der Waldorfschule (pp. 361-373). Stuttgart, Verlag Freies Geistesleben.

Michler, C. (2005). Vier neuere Lehrwerke für den Französischunterricht auf dem Gymnasium. Eine kritische Fallstudie mit Empfehlungen für zukünftige Lehrwerke. Augsburg: Wißner.

Mukundan, J. (2007). Evaluation of English Language Textbooks: Some Important Issues for Consideration, Journal of NELTA, 12 (1\&2), 80-84.

Noriah, I. (2011). Teaching languages online. English Language Teaching Journal, 65(2), 215-217.

Numrich, C. (1996). On becoming a language teacher: Insights from diary studies. TESOL Quarterly, 30, 131-153.

O’Neill, R. (1982). Why use textbooks? ELT Journal, 36(2), 104-111.

Oxford Advanced Learner's Dictionary, (2000). OUP: Oxford.

Peacock, A. \& Cleghorn, A. (Eds.) (2004). Missing the Meaning. The Development and Use of Print and Nonprint Text Materials in Diverse School Settings. New York: Palgrave Macmillan.

Peschel, F. (2005). Das beste Arbeitsblatt ... macht sich überflüssig. Von der Arbeitsblattdidaktik zur Eigenproduktion. Grundschule, 37(12), 9-13.

Podromou, L. (2002). The great ELT textbook debate. MET, 11(4), 25-33.

Richards, J. C. (1996). Teachers' Maxims in Language Teaching. Tesol Quartely, 30(2), 281296.

Sandfuchs, U. (2010). Schulbücher und Unterrichtsqualität - historische und aktuelle Refexionen. In E. Fuchs, J. Kahlert \& U. Sandfuchs (eds.), Schulbuch konkret. Kontexte Produktion Unterricht (pp. 25-40). Bad Heilbrunn: Verlag Ju-lius Klinkhardt.

Sheldon, L. E. (1988). Evaluating ELT textbooks and materials. ELT Journal, 42(4), 237-246. 
Stranks, J. (2012). The construction of English: culture, consumerism and promotion in the ELT global coursebook. ELT Journal, 66(1), 125-127.

Swan, M. (1992). The textbook: bridge or wall? Applied Linguistics and Language Teaching, $2(1), 32-35$.

Thornbury, S. (2009). Slow-release grammar. English Teaching Professional, 61(3), 4-9.

Thornbury, S. (2005). Awareness, Appropriation and Autonomy. English Teaching Professional, 40(9), 11-13.

Tomlinson, B. (2003). Developing Materials for Language Teaching. London: Continuum.

Tomlinson, B. (1998). Materials Development in Language Teaching. Cambridge: Cambridge University Press.

Ur, P. (2012). A Course in English Language Teaching. Cambridge: Cambridge University Press. 